\title{
Phytosynthesized iron nanoparticles: effects on fermentative hydrogen production by Enterobacter cloacae $\mathrm{DH}-89$
}

\author{
DHRUBAJYOTI NATH ${ }^{1}$, AJAY KUMAR MANHAR ${ }^{1}$, KULDEEP GUPTA ${ }^{1}$, \\ DEVABRATA SAIKIA ${ }^{1}$, SHYMAL KUMAR DAS ${ }^{2}$ and MANABENDRA MANDAL ${ }^{1, *}$ \\ ${ }^{1}$ Department of Molecular Biology and Biotechnology, Tezpur University, Napaam, Tezpur 784028 , Assam, India \\ ${ }^{2}$ Department of Physics, Tezpur University, Napaam, Tezpur 784 028, Assam, India
}

MS received 9 June 2015; accepted 24 June 2015

\begin{abstract}
In recent years the application of metal nanoparticles is gaining attention in various fields. The present study focuses on the additive effect of 'green' synthesized iron nanoparticles (FeNPs) on dark fermentative hydrogen $\left(\mathrm{H}_{2}\right)$ production by a mesophilic soil bacterium Enterobacter cloacae. The FeNPs were synthesized by a rapid green method from $\mathrm{FeSO}_{4}$ using aqueous leaf extract of Syzygium cumini. The synthesized FeNPs showed a characteristic surface plasmon resonance peak at $267 \mathrm{~nm}$. The transmission electron microscopy images confirm that the formation of FeNPs was mainly porous and irregular in shape, with an average particle size of 20-25 $\mathrm{nm}$. The presence of iron (Fe) in the synthesized FeNPs was confirmed by energy-dispersive X-ray spectroscopy. The comparative effect of $\mathrm{FeSO}_{4}$ and $\mathrm{FeNPs}$ on batch fermentative $\mathrm{H}_{2}$ production from glucose was investigated. The fermentation experiments reveal that the percentage and yield of $\mathrm{H}_{2}$ in FeNPs supplementation were increased significantly than the control (no supplementation) and $\mathrm{FeSO}_{4}$ containing media. The maximum $\mathrm{H}_{2}$ yield of $1.9 \mathrm{~mol} \mathrm{~mol}^{-1}$ glucose utilized was observed in $100 \mathrm{mg} \mathrm{l}^{-1}$ FeNPs supplementation, with two-fold increase in glucose conversion efficiency. Thus, the result suggests that FeNPs supplementation in place of $\mathrm{FeSO}_{4}$ could improve the bioactivity of $\mathrm{H}_{2}$ producing microbes for enhanced $\mathrm{H}_{2}$ yield and glucose consumption.
\end{abstract}

Keywords. Iron nanoparticles; green synthesis; Syzygium cumini; dark fermentation; biohydrogen production; Enterobacter cloacae.

\section{Introduction}

The green method of nanoparticle synthesis has received immense attention, and is a burning area of research since the last decade. Owing to their unique size-dependent physiochemical properties, metal and metal oxide nanoparticles get varied range of applications in biomedical, optics, mechanics and energy science. ${ }^{1-3}$ A variety of physical and chemical methods have been reported for the synthesis of metal nanoparticles. ${ }^{4-7}$ The necessity of expensive equipment or high energy in physical methods and use of toxic chemicals as well as hazardous by-products formation during chemical synthesis, upsurge the curiosity to find an alternate and safe approach. The green synthesis of nanoparticles using biological materials is considered as a cost-effective, nontoxic and eco-friendly approach. ${ }^{8}$ Biological resources like microorganisms and plant extracts can be used as reducing agents. ${ }^{9-11}$ The plant extract-mediated synthesis of nanoparticles is potentially advantageous over microorganisms because of simple, cost-effective, readily available and relatively reproducible. ${ }^{12,13}$ Plant extracts generally reduce the metal ions in a shorter period of time than microbes. Depending upon the plant type and phytoconstituents concentration, nanoparticles are synthesized within a few

\footnotetext{
*Author for correspondence (mandal@tezu.ernet.in)
}

minutes to hours. ${ }^{14}$ In recent times, green synthesis of iron nanoparticles (FeNPs) of various shapes and sizes have been reported using green tea, ${ }^{15}$ Murraya koenigii leaf extract, ${ }^{16}$ soya bean sprouts and sorghum bran extract. ${ }^{17}$ The abovementioned nanoparticles were successfully applied in various fields like dye degradation, biohydrogen production and waste water treatment. In recent times, the synthesis of silver nanoparticles using leaf and bark extract of Syzygium cumini as reducing agent has been reported. ${ }^{18,19}$ However, there are very few reports on the synthesis of FeNPs using aqueous leaf extract of $S$. cumini.

Hydrogen $\left(\mathrm{H}_{2}\right)$ a sustainable energy source, considered as a promising substitute of fossil fuel. It is a clean fuel, as it produces only water instead of green house gases on combustion. ${ }^{20}$ Among various methods of $\mathrm{H}_{2}$ production, dark fermentative process has been recognized as the most suitable because of its ecofriendly and energy efficient status. ${ }^{21}$ However, the major challenge in this method is the low yield and slow production rate. Therefore, the search for a novel approach is required to accelerate the $\mathrm{H}_{2}$ production rate and enhance the yield. Micronutrients like iron and magnesium are well known for their involvement in the activation or function of many enzymes and co-enzymes, and are also vital for the growth of most microorganisms. ${ }^{22}$ Hydrogenases, a group of metalloenzyme catalyses the $\mathrm{H}_{2}$ formation in a variety of microorganisms. They have very unique 
active sites and are classified based upon the active site metal composition as: [Fe], [Fe-Fe], and [Ni-Fe] hydrogenases. ${ }^{23}$ Thus, the supplementation of suitable micronutrients is likely to enhance the activity of these enzymes for high $\mathrm{H}_{2}$ yield. Iron is generally used as a media component in the fermentation medium for $\mathrm{H}_{2}$ production. Mainly, iron is a component of ferredoxin which acts as an electron carrier in hydrogenases. ${ }^{17} \mathrm{~A}$ few studies have reported on improved $\mathrm{H}_{2}$ yield and more substrate utilization by supplementing production media with metal nanoparticles. ${ }^{2,3,24,25}$ In the present study a clean method is applied for the synthesis of FeNPs using water extract of the $S$. cumini leaf. The synthesized FeNPs is used as media supplement to enhance the dark fermentative $\mathrm{H}_{2}$ production by the isolated strain DH-89 in glucose-based batch fermentation.

\section{Materials and methods}

\section{$2.1 \quad \mathrm{H}_{2}$ producing bacterial strain}

The $\mathrm{H}_{2}$ producing bacterial strain was isolated from soil sample of paddy field from North-East India. For this, $1 \mathrm{~g}$ of the soil sample was serially diluted with $0.85 \% \mathrm{NaCl}(\mathrm{w} / \mathrm{v})$ and then plated on nutrient agar plates, incubated at $37^{\circ} \mathrm{C}$ for 24 h. Different bacterial colonies based on their colony morphology were obtained and subsequently maintained as pure cultures for screening of potent $\mathrm{H}_{2}$ producers.

\subsection{Preparation of leaf extract}

Freshly collected $S$. cumini leaves were washed three times with water and air dried. The dried leaves were then grinded into fine powder. The extract was prepared by mixing $50 \mathrm{~g}$ of finely powdered leaf with 1 litre distilled water, followed by boiling for $10 \mathrm{~min}$ in boiling water bath. The extract was then filtered through Whatman No. 1 filter paper and the filtrate was used as reducing agent for nanoparticle synthesis.

\subsection{Synthesis of FeNPs using leaf extract}

Different concentrations of leaf extracts and $\mathrm{FeSO}_{4}$ solution were reacted to obtain the optimum concentration for synthesis of FeNPs. In a typical synthesis, $25 \mathrm{ml}$ of plant extract was slowly added to $475 \mathrm{ml}$ of $1 \mathrm{mM} \mathrm{FeSO}_{4}$ solution with constant stirring for $10 \mathrm{~min}$ at room temperature. A visible colour change of $\mathrm{FeSO}_{4}$ from light yellow to dark black indicates the formation of FeNPs. The colloidal mixture was then centrifuged $\left(12,000 \mathrm{rpm}, 20^{\circ} \mathrm{C}\right)$ for $10 \mathrm{~min}$. The pellet was washed with distilled water and freeze dried for further use.

\subsection{Characterization of the synthesized FeNPs}

UV-visible spectrophotometer (Thermo Fischer Scientific, Evolution 201) was used to perform optical measurements. The UV-vis spectrum of FeNPs was taken in quartz cuvettes, using distilled water as a reference solvent. UV-visible analysis was carried out by continuous scanning from 200 to $600 \mathrm{~nm}$. X-ray diffraction (XRD) patterns of the FeNPs were obtained by X-ray diffractometer (Miniflex, Rigaku Corporation Japan). The scanning was performed from $10^{\circ}$ to $70^{\circ} 2 \theta$ with $2 \mathrm{~min}^{-1}$ of scanning rate. For surface morphology study, scanning electron microscopy (SEM-JEOL JSM-6390 LV, Japan) and transmission electron microscopy (TEMTECNAI G 20 S-TWIN, $200 \mathrm{kV}$ ) analysis were done. The elemental composition of the synthesized FeNPs was determined using energy-dispersive X-ray (EDX) spectrophotometer (JEOL-JSM 6390, Japan). Fourier transform infrared (FTIR) spectra of the aqueous leaf extract and FeNPs were analysed by FTIR spectrophotometer (Perkin Elmer 1000 FT-IR spectrometer).

\subsection{Experimental procedure for dark fermentative $\mathrm{H}_{2}$ production}

Batch experiments were conducted for dark fermentative $\mathrm{H}_{2}$ production in $125 \mathrm{ml}$ BOD bottle with a working volume of $100 \mathrm{ml}$ under anaerobic condition at $37^{\circ} \mathrm{C}$. The fermentation medium was mineral salt medium (MSM), consisted of macronutrients $\left(\mathrm{g} \mathrm{l}^{-1}\right)$ : $\left(\mathrm{NH}_{4}\right)_{2} \mathrm{SO}_{4}, 2 ; \mathrm{Na}_{2} \mathrm{HPO}_{4}, 2.61$; $\mathrm{KH}_{2} \mathrm{PO}_{4}, 4.75 ; \mathrm{MgSO}_{4}, 0.8$; glucose, 10; and micronutrients $\left(\mu \mathrm{g} \mathrm{l}^{-1}\right)$ : $\mathrm{CaCl}_{2}, 500 ; \mathrm{MnSO}_{4}, 100 ; \mathrm{H}_{3} \mathrm{BO}_{3}, 10 ; \mathrm{ZnSO}_{4}$, 70; and $\mathrm{MoO}_{3}, 50$. The $\mathrm{pH}$ of the medium was adjusted to 7.0 before autoclaving. The supplementation of $\mathrm{FeSO}_{4}$ and FeNPs in MSM was done in the range from 0 to $200 \mathrm{mg} \mathrm{l}^{-1}$ to evaluate and compare the effect on $\mathrm{H}_{2}$ production. After bacterial inoculation, the bottles were made air tight using glass stoppers and initial anaerobic condition was established by flushing nitrogen gas. The evolved gases from fermenters were collected by the water displacement method under acidic water. The gas collection and analysis were carried out till the gas production was ceased. ${ }^{26}$

\subsection{Analytical methods}

The evolved biogas during fermentation was measured through the water displacement method and analysed by gas chromatograph (Nucon GC5765) equipped with Porapak$\mathrm{Q}$ and molecular sieve columns using thermal conductivity detector. ${ }^{27}$ The operating temperatures of the oven, injector and the detector were set at 60,80 and $110^{\circ} \mathrm{C}$, respectively. Argon served as carrier gas at a flow rate of $20 \mathrm{ml} \mathrm{min}^{-1}$. The concentration of glucose was estimated by the DNS method. ${ }^{28}$ Cell growth was measured indirectly by measuring the protein content of whole-cell extract at the end of fermentation. ${ }^{29}$

\section{Results and discussion}

\subsection{Screening and identification of $\mathrm{H}_{2}$ producing bacterial strain}

Purified bacterial isolates were screened for $\mathrm{H}_{2}$ production by the method described earlier for fermentation. In this 


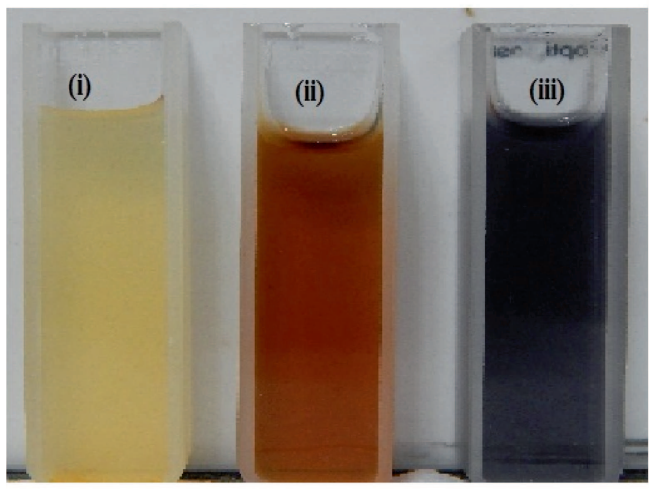

(a)

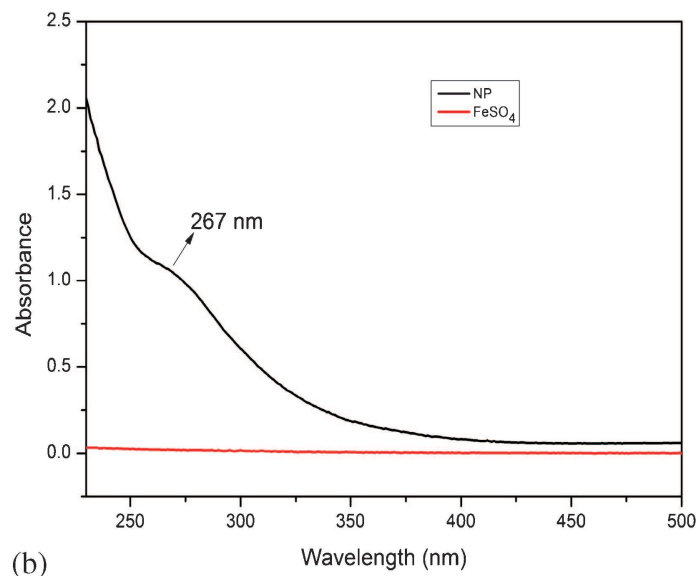

(b)

Figure 1. (a) Visible colour change during the synthesis of FeNPs: (i) cuvette containing $\mathrm{FeSO}_{4}$ solution, (ii) leaf extract and (iii) synthesized colloidal nanomaterial, and (b) UV-visible absorption spectra of synthesized FeNPs and $\mathrm{FeSO}_{4}$.

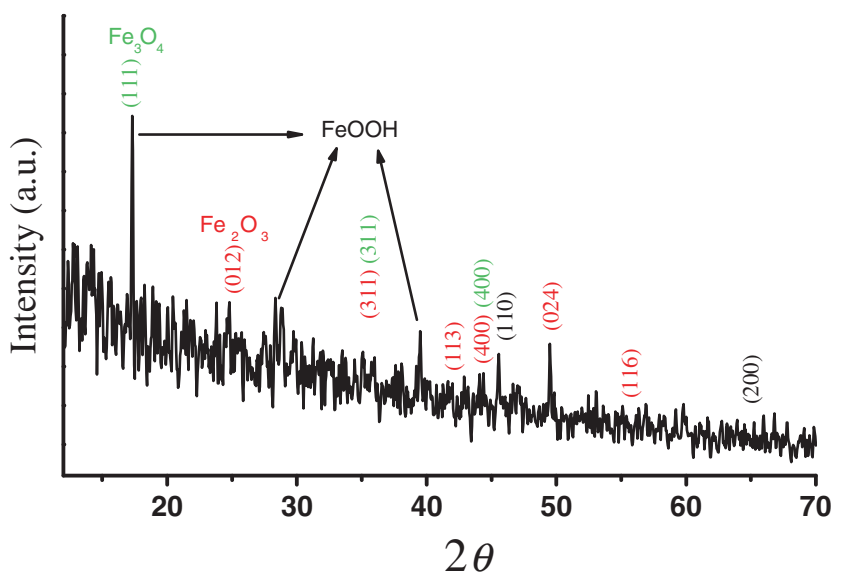

Figure 2. XRD patterns of synthesized FeNPs.

study, strain DH-89 was selected on the basis of maximum biogas production during screening. Identification of the selected strain DH-89 was carried out by $16 \mathrm{~S}$ rDNA gene sequencing analysis. Finally the sequence was submitted to the NCBI genebank and the strain was named as Enterobacter cloacae DH-89 strain (NCBI Accession no. KP723362).

\subsection{Characterization of FeNPs}

3.2a UV-vis spectroscopy and XRD study: The formation of FeNPs was visually observed by change in colour of the parent precursor and reducing agent mixture (figure 1a) during the synthesis. Figure $1 \mathrm{~b}$ shows the UV-vis spectra of the aqueous solution of $\mathrm{FeSO}_{4}$ and the synthesized colloidal material. A prominent difference can be observed in the spectra. The synthesized FeNPs showed absorption from $350 \mathrm{~nm}$ with a peak at $267 \mathrm{~nm}$, which is typical for iron nanomaterials. The XRD pattern of the FeNPs (figure 2) is complex and shows several small intensity diffraction peaks. The prominent diffraction peaks can beindexed to $\alpha$-FeOOH (JCPDS no. 29-0713), $\mathrm{Fe}_{2} \mathrm{O}_{3}$ (JCPDS no. 33-0664) and $\mathrm{Fe}_{3} \mathrm{O}_{4}$ (JCPDS no. 19-0629). Most of the peaks from the phases overlap each other. Since the peaks are not intense, it is difficult to determine the crystallite size using the Scherrer formula.

3.2b SEM, TEM, EDX and FTIR analysis: The morphology of the FeNPs was investigated by electron microscopy. Figure 3a shows the SEM image. It indicated the formation of random shaped aggregates of micron-sized particles. It can be attributed to uncontrolled nanoparticle agglomeration during the synthesis. This fact is clearly evident from the TEM images (figure $3 b$ ). It showed agglomerated clusters of nanoparticles of primary sizes in the range of 20-25 nm. Careful observation of the TEM images indicated that the material is porous. The EDX spectrum (figure 4) shows the elemental profile of FeNPs, primarily composed of $\mathrm{C}, \mathrm{O}, \mathrm{S}$ and $\mathrm{Fe}$. The $\mathrm{C}$ and $\mathrm{O}$ are mainly from the compounds present in plant extracts, while $\mathrm{Fe}$ and $\mathrm{S}$ from the $\mathrm{FeSO}_{4}$ precursor. The elemental percentage was observed as $40.54 \% \mathrm{C}$, $50.82 \% \mathrm{O}, 2.45 \% \mathrm{~S}$ and $6.19 \% \mathrm{Fe}$. The FTIR spectra of the plant extract and FeNPs are shown in figure 5. After comparing the spectra, it was observed that some peaks were shifted and missed. However, few additional peaks were also emerged in case of synthesized FeNPs. The peak positioned at $3428 \mathrm{~cm}^{-1}$ in the plant extract was shifted to $3421 \mathrm{~cm}^{-1}$ in case of FeNPs, similarly peaks at 1739, 16231392 and $1052 \mathrm{~cm}^{-1}$ were shifted to $1732,1630,1334$ and $1020 \mathrm{~cm}^{-1}$, respectively. The peak at $1456 \mathrm{~cm}^{-1}$ in plant extract was found missing in the synthesized FeNPs and emergence of new peaks were observed at 618,520 and $468 \mathrm{~cm}^{-1}$. The absorption peaks observed in the range of $1800-1500 \mathrm{~cm}^{-1}$ can be assigned as peak due to double bond stretching between $\mathrm{C}=\mathrm{O}$ and $\mathrm{C}=\mathrm{C}$. The peaks observed in the range of $1400-1000 \mathrm{~cm}^{-1}$ can be assigned due to stretching vibration of single bond between $\mathrm{C}-\mathrm{O}$ and $\mathrm{N}-\mathrm{H}$. These stretching's arises from the organic moieties of the plant extract present 

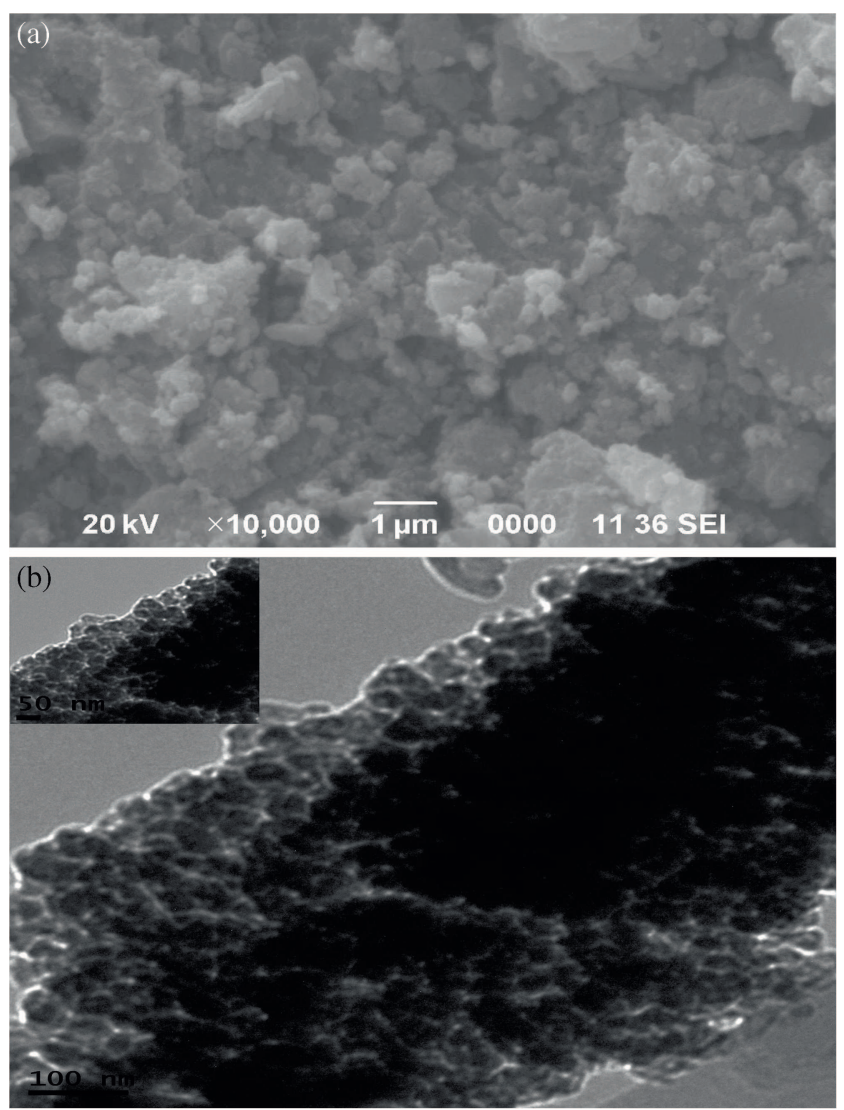

Figure 3. (a) SEM image of the synthesized FeNPs and (b) TEM images of the synthesized FeNPs at bar scale of 50 and $100 \mathrm{~nm}$.

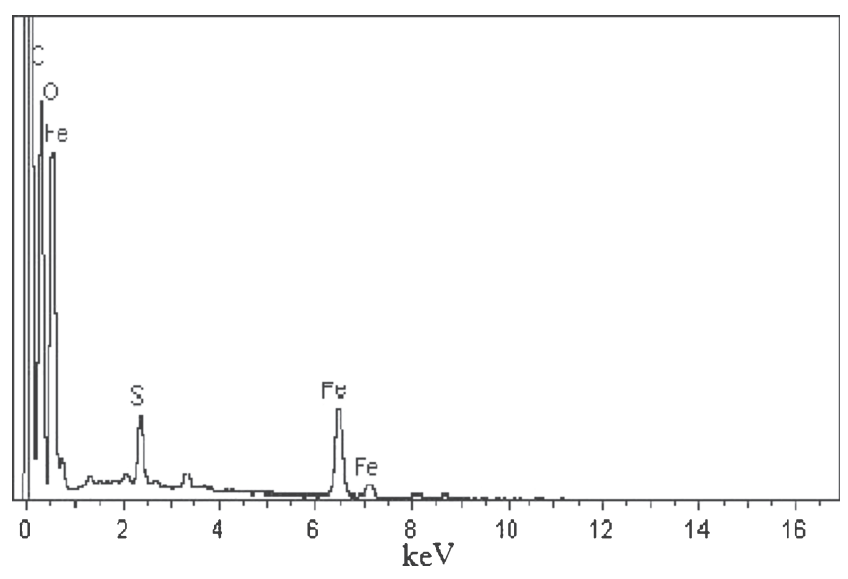

Figure 4. EDX spectrum of the synthesized FeNPs.

in the synthesized FeNPs. The absorption band at 468 and $520 \mathrm{~cm}^{-1}$, in case of FeNPs correspond to the $\mathrm{Fe}-\mathrm{O}$ stretches of $\mathrm{Fe}_{2} \mathrm{O}_{3}$ and $\mathrm{Fe}_{3} \mathrm{O}_{4} \cdot{ }^{30,31}$

\subsection{Effects of $\mathrm{FeSO}_{4}$ and $\mathrm{FeNPs}$ on batch fermentative $\mathrm{H}_{2}$ production}

The effects of $\mathrm{FeSO}_{4}$ and FeNPs on fermentative $\mathrm{H}_{2}$ production using E. cloacae DH-89 are shown in figure 6. It

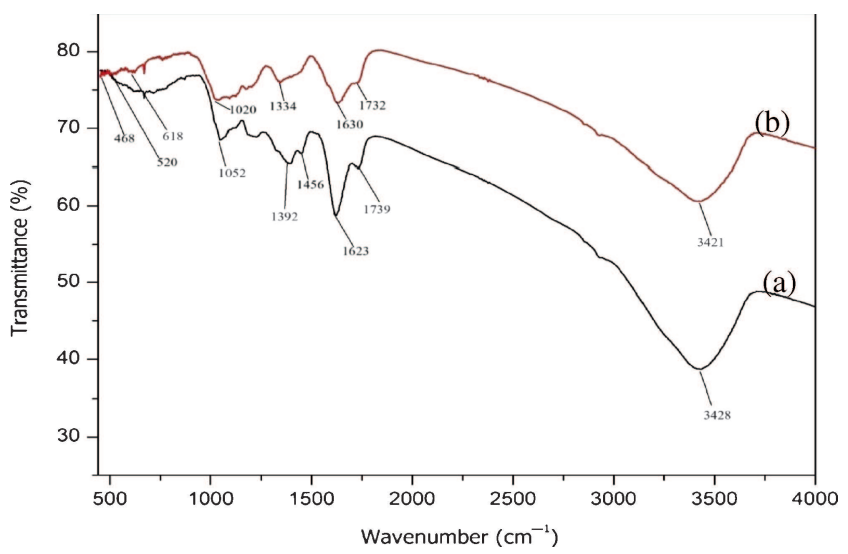

Figure 5. FTIR spectra of (a) S. cumini leaf extract and (b) synthesized FeNPs .

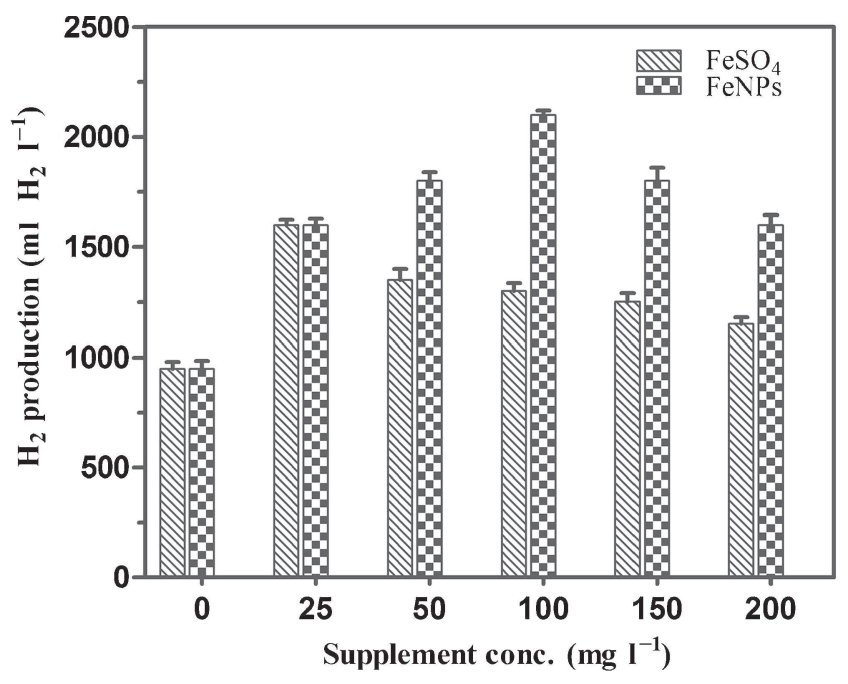

Figure 6. $\mathrm{H}_{2}$ production at different concentrations of $\mathrm{FeSO}_{4}$ and FeNPs supplementation.

was found that the $\mathrm{H}_{2}$ production increases on the addition of both the form of iron. The $\mathrm{H}_{2}$ production in the control (no supplementation) was $950 \mathrm{ml} \mathrm{l}^{-1}$ of fermentation media, which was noticeably increased by supplementation of $\mathrm{FeSO}_{4}$ at a concentration of $25 \mathrm{mg} \mathrm{l}^{-1}$ and then decreased with further increase in the concentration from 50 to $200 \mathrm{mg} \mathrm{l}^{-1}$. With the optimum concentration of $25 \mathrm{mg} \mathrm{l}^{-1}$ $\mathrm{FeSO}_{4}$ supplementation the $\mathrm{H}_{2}$ production was increased to $1600 \mathrm{ml} \mathrm{l}^{-1}$. The addition of high concentration of $\mathrm{FeSO}_{4}$ (above $25 \mathrm{mg} \mathrm{l}^{-1}$ ) suppressed the activity of bacterium, consequently a low $\mathrm{H}_{2}$ production. A similar kind of result, i.e., the higher concentration of $\mathrm{FeSO}_{4}$ addition decreases the $\mathrm{H}_{2}$ production has been reported. ${ }^{16}$ However, supplementation of green synthesized FeNPs in place of $\mathrm{FeSO}_{4}$ was found to further increase the $\mathrm{H}_{2}$ production. The maximum $\mathrm{H}_{2}$ production of $2100 \mathrm{ml}$ was achieved at $100 \mathrm{mg} \mathrm{l}^{-1}$ FeNPs supplementation and it was decreased by increasing the concentration above $100 \mathrm{mg}^{-1}$. The present finding suggests that the supplementation of iron can be replaced by ironbased nanoparticles for better $\mathrm{H}_{2}$ production. The fact is that, 


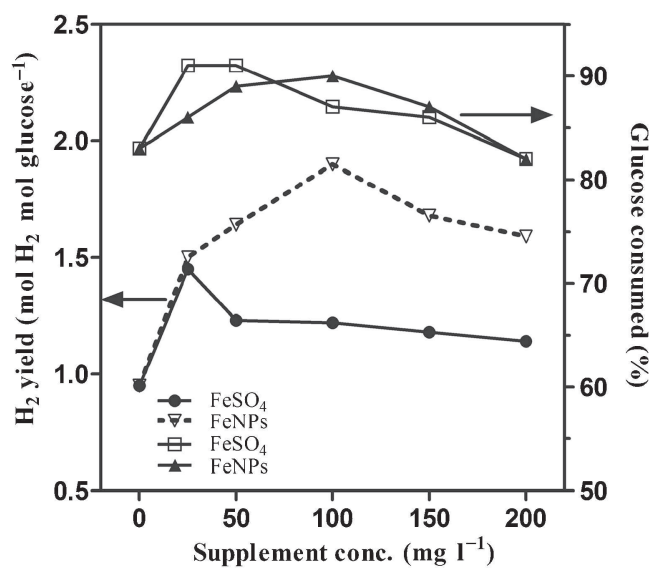

(a)

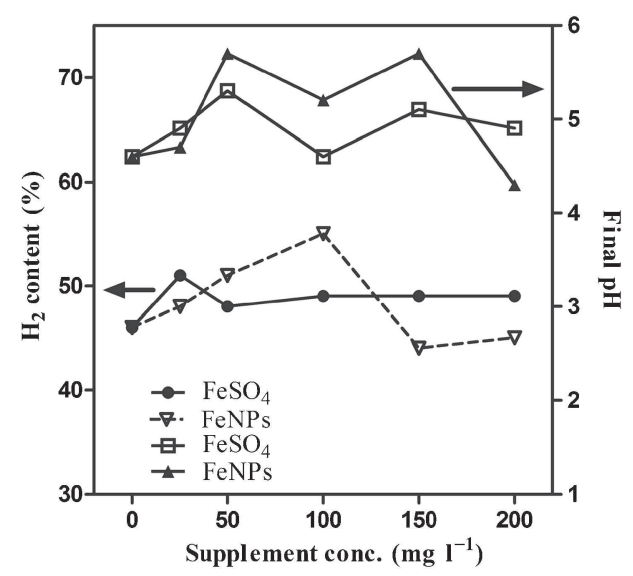

(b)

Figure 7. Effects of $\mathrm{FeSO}_{4}$ and FeNPs supplementation on (a) $\mathrm{H}_{2}$ yield and glucose consumption and (b) $\mathrm{H}_{2}$ content and final $\mathrm{pH}$.

Table 1. Effects of $\mathrm{FeSO}_{4}$ and FeNPs supplementation on cell growth and glucose conversion efficiency.

\begin{tabular}{|c|c|c|c|c|c|c|c|c|c|c|c|}
\hline \multirow{2}{*}{$\frac{\text { Supplement type }}{\text { Conc. }\left(\mathrm{mg} \mathrm{1}^{-1}\right)}$} & \multirow{2}{*}{$\frac{\text { Control }}{0}$} & \multicolumn{5}{|c|}{$\mathrm{FeSO}_{4}$} & \multicolumn{5}{|c|}{ FeNPs } \\
\hline & & 25 & 50 & 100 & 150 & 200 & 25 & 50 & 100 & 150 & 200 \\
\hline Conversion efficiency ${ }^{\mathrm{a}}(\%)$ & 23.8 & 36.3 & 30.8 & 30.5 & 29.5 & 28.5 & 37.5 & 41 & 47.5 & 42 & 39.8 \\
\hline Cell growth ${ }^{\mathrm{b}}$ & 52.7 & 55.45 & 55.45 & 54.95 & 54.7 & 52 & 53.7 & 59.45 & 61.7 & 56.95 & 54.7 \\
\hline
\end{tabular}

${ }^{a}$ Yield of $4 \mathrm{~mol} \mathrm{H}_{2}$ mol glucose ${ }^{-1}$ is equal to $100 \%$.

${ }^{\mathrm{b}}$ Protein concentration $\mathrm{mg} \mathrm{dl^{-1 }}$ of whole-cell extract.

iron is a fundamental component of ferredoxin, which acts as an electron carrier in the hydrogenases, responsible for $\mathrm{H}_{2}$ production. Hence, at a certain concentration of iron or FeNPs supplementation increases the ferredoxin activity during the fermentation process, which leads to enhanced $\mathrm{H}_{2}$ production. ${ }^{32,33}$

\subsection{Effects of $\mathrm{FeSO}_{4}$ and $\mathrm{FeNPs}$ on $\mathrm{H}_{2}$ yield, glucose conversion efficiency and cell growth}

The experimental data for the effects of $\mathrm{FeSO}_{4}$ and FeNPs on $\mathrm{H}_{2}$ yield and glucose consumption efficiency are shown in figure 7a. Without any iron supplementation, the $\mathrm{H}_{2}$ yield was $0.95 \mathrm{~mol} \mathrm{~mol}^{-1}$ glucose utilized, which was increased to $1.45 \mathrm{~mol} \mathrm{~mol}^{-1}$ glucose utilized with supplementation of $25 \mathrm{mg} \mathrm{l}^{-1} \mathrm{FeSO}_{4}$. Further it was decreased with increasing the $\mathrm{FeSO}_{4}$ concentration above $25 \mathrm{mg} \mathrm{l}^{-1}$. However, supplementation of FeNPs results into two-fold increase in the $\mathrm{H}_{2}$ yield as compared to control. The yield was observed $1.9 \mathrm{~mol} \mathrm{~mol}^{-1}$ glucose utilized with $100 \mathrm{mg} \mathrm{l}^{-1}$ FeNPs. The percentage of $\mathrm{H}_{2}$ in the evolved biogas was found maximum (55\%) with optimum concentration of FeNPs supplementation (figure $7 \mathrm{~b}$ ). Table 1 shows the experimental data for cell growth and glucose conversion efficiency. The cell growth was observed maximum in case of FeNPs supplementation as compared to control as well as $\mathrm{FeSO}_{4}$ supplementation. The conversion efficiency $(\%)$ is a measure of practical conversion of glucose to $\mathrm{H}_{2}$ during fermentation. Theoretically, $1 \mathrm{~mol}$ of glucose produce $4 \mathrm{~mol}$ of $\mathrm{H}_{2}$, considered as conversion efficiency value of $100 \% .{ }^{34}$ A two-fold increases in conversion efficiency was observed in FeNPs supplementation as compared to the control. The maximum conversion efficiency of $47.5 \%$ was observed at $100 \mathrm{mg} \mathrm{l}^{-1}$ FeNPs supplementation. The results suggest that the FeNPs supplementation also improves the metabolic process of glucose by the bacterial strain resulted into higher carbon flux for $\mathrm{H}_{2}$ production.

\section{Conclusions}

In this present study, isolation and identification of soil bacterium E. cloacae DH- 89 was done for fermentative $\mathrm{H}_{2}$ production. The strain can produce $\mathrm{H}_{2}$ by batch fermentation with a yield of $0.95 \mathrm{~mol} \mathrm{~mol}^{-1}$ glucose consumed. The efficiency of the strain for $\mathrm{H}_{2}$ production was increased by iron supplementation in the fermentation media. The iron supplementation was done with $\mathrm{FeSO}_{4}$ and FeNPs. The successfully synthesized FeNPs using aqueous leaf extract of $S$. cumini was characterized and this method can be used for rapid green synthesis of FeNPs. The synthesized FeNPs supplementation with a concentration of $100 \mathrm{mg}^{-1}$ was observed to enhance the $\mathrm{H}_{2}$ production potential of the bacterium by two-fold with increasing glucose consumption rate and cell biomass yield. 


\section{Acknowledgements}

This research work was financially supported by Department of Biotechnology (Ref. No. BT/212/NE/TBP/2011 dated December 14, 2011), New Delhi, India. Mr D Nath is thankful to CSIR, India, for providing research fellowship (Award no. 09/796/0060/2015-EMR-1). We also acknowledge the help extended by Tezpur University, Assam, India, by providing infrastructure and other necessary facilities to carry out the research work successfully.

\section{References}

1. Mody V V, Siwale R, Singh A and Mody H R 2010 J. Pharm. Bioallied Sci. 2282

2. Zhao W, Zhang Y, Du B, Wei D, Wei Q and Zhao Y 2013 Bioresour. Technol. 142240

3. Mullai P, Yogeswari M K and Sridevi K 2013 Bioresour. Technol. 141212

4. Farrell D, Majetich S A and Wilcoxon J P 2003 J. Phys. Chem. B 10711022

5. Koltypin Y, Perkas N and Gedanken A 2004 J. Mater. Chem. 142975

6. Choi C J, Tolochko O and Kim B K 2002 Mater. Lett. 56289

7. Xiaomin N, Xiaobo S, Huagui Z, Dongen Z, Dandan Y and Qingbiao Z 2005 J. Cryst. Growth 275548

8. Mahdavi M, Namvar F, Ahmad M B and Mohamad R 2013 Molecules 185954

9. Ahmad A, Mukherjee P, Mandal D, Senapati S, Khan M I, Kumar R and Sastry M 2002 J. Am. Chem. Soc. 12412108

10. Ahmad A, Senapati S, Khan M I, Kumar R and Sastry M 2003 Langmuir 193550

11. Mittala A K, Chisti Y and Banerjee U C 2013 Biotechnol. Adv. 31346

12. Iravani S 2011 Green Chem. 132638

13. Gupta K, Hazarika S N, Saikia D, Namsa N D and Mandal M 2014 Mater. Lett. 12567

14. Rai M, Yadav A and Gade A 2008 Crit. Rev. Biotechnol. 28 277
15. Shahwan T, Sirriah S A, Nairat M, Boyaci E, Eroğlu A E, Scott T B and Hallam K R 2011 Chem. Eng. J. 172 258

16. Mohanraj S, Kodhaiyolii S, Rengasamy M and Pugalenthi V 2014 Appl. Biochem. Biotechnol. 173318

17. Cai Y, Shen Y, Xie A, Li S and Wang X 2010 J. Magn. Magn. Mater. 3222938

18. Gupta K, Barua S, Hazarika S N, Manhar A K, Nath D, Karak N, Namsa N D, Mukhopadhyay R, Kalia V C and Mandal M 2014 RSC Adv. 452845

19. Prasad R and Swamy V S 2013 J. Nanopart. 20131

20. Patel A K, Debroy A, Sharma S, Saini R, Mathur A, Gupta R and Tuli D K 2015 Bioresour. Technol. 175291

21. Patel S K S, Kumar P, Singh M, Lee J K and Kalia V C 2015 Bioresour. Technol. 176136

22. Liu B F, Ren N Q, Ding J, Xie G J and Guo W Q 2009 Int. J. Hydrogen Energy $\mathbf{3 4} 721$

23. Kim D H and Kim M S 2011 Bioresour. Technol. 1028423

24. Mohanraj S, Anbalagan K, Kodhaiyolii S and Pugalenthi V 2014 J. Biotechnol. 19287

25. Zhang Y and Shen J 2007 Int. J. Hydrogen Energy 3217

26. Porwal S, Kumar T, Lal S, Rani A, Kumar S, Cheema S, Purohit H J, Sharma R, Patel S K S and Kalia V C 2008 Bioresour. Technol. 995444

27. Patel S K S, Singh M, Kumar P, Purohit H J and Kalia V C 2012 Biomass Bioenergy 36218

28. Miller G L 1959 Anal. Chem. 31426

29. Sparling R, Islam R, Cicek N, Carere C, Chow H and Levin D B 2006 Can. J. Microbiol. 52681

30. Chen Z X, Jin X Y, Chen Z, Megharaj M and Naidu R 2011 J. Colloid Interface Sci. 36601

31. Prasad K S, Gandhi P and Selvaraj K 2014 Appl. Surf. Sci. 317 1052

32. Wang J and Wan W 2008 Int. J. Hydrogen Energy 331215

33. Yang H and Shen J 2006 Int. J. Hydrogen Energy 312137

34. Abdeshahian P, Al-Shorgani N K N, Salih N K M, Shukor H, Kadier A, Hamid A A and Kalil M S 2014 Int. J. Hydrogen Energy 3912524 